\title{
PHOSPHORUS LOADING FROM FISH FARMING ACTIVITIES TO WADASLINTANG RESERVOIR WATERS
}

\author{
Agatha Sih Piranti ${ }^{1 *}$, Diana RUS Rahayu ${ }^{1}$, Gentur Waluyo ${ }^{2}$ \\ ${ }^{1}$ Department of Environmental Biology, Faculty of Biology, Unsoed, Karangwangkal \\ Purwokerto 53122, Central Java, Indonesia \\ ${ }^{2}$ Departments of Geology, Faculty of Engineering Unsoed, Blater Purbalingga, 53371, \\ Central Java, Indonesia
}

\begin{abstract}
Wadaslintang Reservoir located in Wonosobo Regency of Central Java provides to fish farming area using floating net cage. There are 2 feeding system applied that are semi intensively system managed by local community and super intensively managed by PT. Aquafarm. Both different feeding systems resulted in the amount of pollutant load coming into the reservoirs in the form of total $\mathrm{P}$ derived from the remaining feed and feces of fish entering into the reservoir. This can trigger the eutrophication condition of the reservoir waters. The purposes of this study were 1) to calculate the capacity of Wadaslintang reservoir to phosphorus load based on its morphometry and hydrology, 2) to evaluate the capacity of wadaslintang reservoir to Phosphorus load from floating net cage activities in wadaslintang reservoir, and 3) to design the program on the reducing load of Total Phosphorus from floating net activities in wadaslintang reservoir. The research was conducted by survey method in the Wadaslintang Reservoir during January 2016 in both locations of floating net cage fish farming. Parameters measured were $\mathrm{P}$ content in fish and $\mathrm{P}$ content of feed used in both cultivation systems, and $\mathrm{P}$ concentration of reservoir water. The amount of pollutant load coming into the reservoir and its impact on the $\mathrm{P}$ concentration of water was calculated using the formula. The results showed that Wadaslintang Reservoir to phosphorus load capacity was 106,56 ton $\mathrm{P} /$ year. The Phosphorus load from floating net cage was 216,2 ton $\mathrm{P} /$ year. The P load from PT. Aquafarm have exceeded the capacity as much as 70,74 ton $\mathrm{P} /$ year. In general the existence of fish farming system using floating net cage in Wadaslintang Reservoir has contributed to increase the concentration of $\mathrm{P}$ equal to $43,9 \%$ or in other words as much as $50 \%$ of $\mathrm{P}$ load that goes into reservoir of wadaslintang. Programs designed to reduce the phosphorus load could be done by reducing the number of floating net and decreasing all the activities in the catchment area up to $50 \%$ to fulfill phosphorus standard of $100 \mathrm{mg} / \mathrm{m}^{3}$.
\end{abstract}

Corresponding author: agatha.piranti@gmail.com 


\section{INTRODUCTION}

Wadaslintang Reservoir is located in Wadaslintang sub-district, Wonosobo Regency of Central Java Province, Indonesia. As a wadaslintang dam ecosystem functions as a reservoir of water from its catchment area, so the impact of human activities on DTA such as settlement, livestock, agriculture and industry and mining affect the water quality of the reservoir. Activities in reservoir water such, as fish cultivation using KJA then the waste is also a source of pollutant water reservoir. Therefore, the pollutant load comes from various sources, both external (coming from the catchment area) and from the internal reservoir must be calculated so that the incoming waste does not exceed its capacity. The pollution load from various sources will increase along with the increase of population and other activities in the catchment area

The main function of the Wadaslintang Reservoir is to fulfill the irrigation water requirement for 33.279 ha of paddy field, which are located in Kebumen and Purworejo districts. Drinking water and water for fish cultivation area using floating net cages. As a function as fish farming area using floating net cage, there are 2 (two) cultivation method which is used based on ownership and feeding method applied in Wadaslintang Reservoir which is semi intensively done by Community around reservoir called Forum Komunikasi Tani Nelayan (FKTN) Sejahtera Mandiri and super intensively by PT. Aquafarm. Semiintensive fish farming requires a moderate level of inputs and fish production is increased by the use of fertiliser and/or supplementary feeding. Intensive fish farming involves a high level of inputs and stocking the ponds with as many fish as possible. The fish are fed supplementary feed, while natural food production plays a minor role [1]. Super intensive feeding system conducted by PT Aquafarm done with feeding in adlibitum for 15 minutes until the fish full and no appetite again.

Fish cultivation activities using KJA intensively will bring the consequences that many feeds are not utilized by pet fish and will fall to the bottom of the waters. Lukman \& Hidayat [2] stated that the remaining feed in the form of fish feces that fell into the waters about $50 \%$ of the feed given. Abery et al [3] stated that wastewater feed is wasted to waters estimated at about $30-40 \%$. Sukadi [4]. The feed given to fish does fish consume only $70 \%$ and the remaining $30 \%$ will be released to the lake water bodies as pollutants or waste. Therefore, Garno [5] states that fish feed is the highest contributor of organic materials in lakes/reservoirs $(80 \%)$ in producing environmental impacts of water quality degradation caused by eutrophication conditions.

Decrease in water quality due to eutrophication will reduce water function and disrupt the ecosystem in it. Human activity is the most influential factor on the improvement of organic matter. The organic material will decompose and increase the phosphorus and nitrogen elements in the water. Fishery cultivation activity using karamba is the most human activity done in reservoir wadaslintang so it is suspected to cause the entry of organic materials, especially the phosphorus element large enough to the body of water. The high concentration of total phosphorus (total-P) indicates that the organic material entering the water is also high. Phosphorus in the waters of the lake becomes a determinant of growth for phytoplankton or Alga. Phytoplankton or algae can act as one ecological parameter that can describe the condition of a waters and is also an important biotic component in the metabolism of water bodies, since it is the primary link in the food chain of aquatic ecosystems. Changes in the number and types of plankton populations in the waters can illustrate the state of the structure of aquatic communities. Abundance of phytoplankton that is too large and dominated by certain species alone can be used as an indicator that the eutrophication waters. 
Control of eutrophication can be done by limiting the phosphorus entering the reservoir [6]. The limitation of phosphorus can be done by reducing the amount of karamba if its impact has exceeded the carrying capacity of the lake / reservoir as well as the management of good and proper fish feeding [7]. The management of aquaculture using good and proper karamba will increase the productivity of the fishery itself. Therefore, the activity or production of aquaculture in the waters of the lake should be determined based on the load capacity of the phosphorus contamination. The capacity of lake phosphorus pollution load is the ability of lake water to receive input load of phosphorus contamination without causing lake water to be polluted based on environmental characteristic and condition around it ie lake morphology and hydrology covering area, volume, depth and water discharge; quality and trophic status; water quality standard requirements and allocation of pollution load from various sources and types of water. In order for the existence of the reservoir and its function can be sustainable then the water resources need to be maintained so that its quality can meet the required quality standard. Therefore, the purpose of this study is 1) to calculate the capacity of Wadaslintang Reservoir to phosphorus load based on its morphometry and hydrology, 2) to evaluate the capacity of Wadaslintang Reservoir to Phosphorus load from floating net cage activities in Wadaslintang Reservoir, and 3) to design the program on the reducing load of Total Phosphorus from floating net activities in Wadaslintang Reservoir.

\section{MATERIALS AND METHODS}

The research was conducted in Wadaslintang Reservoir at the area of floating net cage activities owned by the community called Forum Komunikasi Tani Nelayan (FKTN) Sejahtera Mandiri and the other owned by PT. Aquafarm (Figure 1).

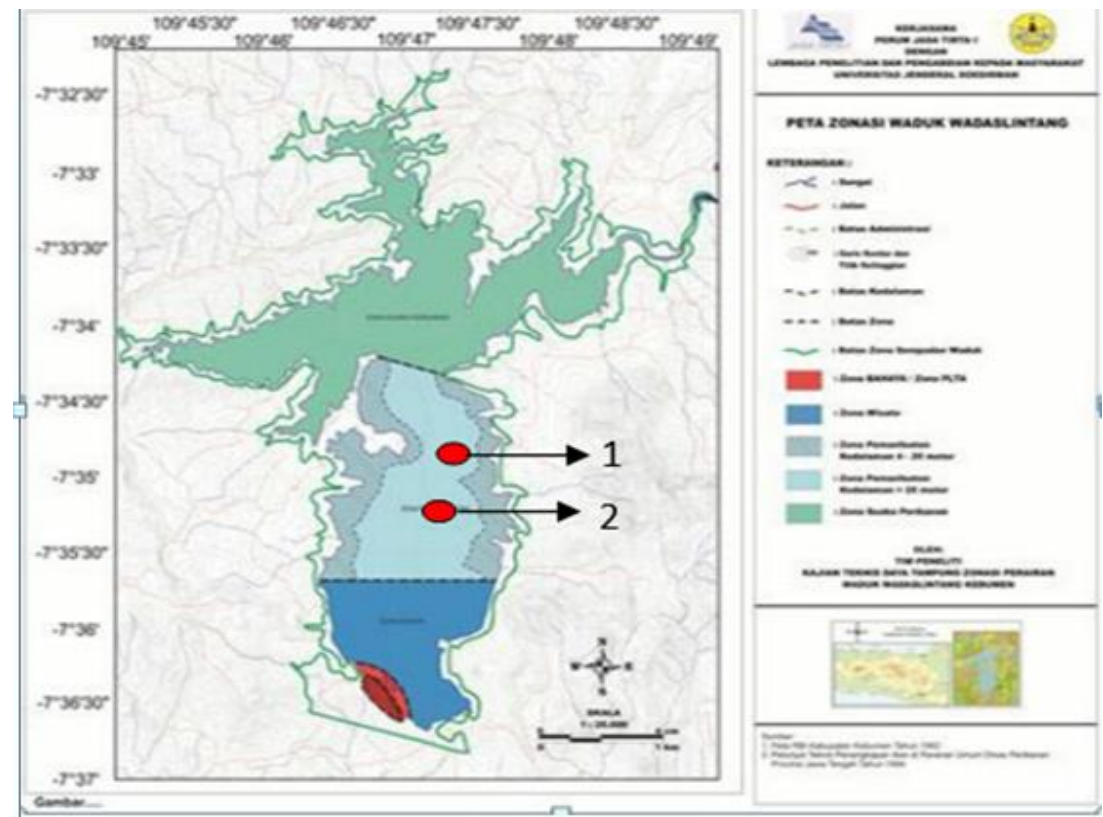

Source : Piranti et al, [8]

Fig 1. Sampling Location in the area of Floating Net Cage in Wadaslintang Reservoir

Sampling was conducted in Januari 2016 by random sampling. Sampling of aquatic fish, sediments and fish taken in the floating net cage area of community (FKTN Sejahtera 
mandiri) and PT. Aquafarm with 3 replicates each places (floating net cage unit). The parameters measured were Total $\mathrm{P}$ concentration in water, sediment and fish. The aquaculture data was obtained by taking direct interviews with the head of FKTN Mandiri Sejahtera (Mr. Nurdin) and PT Aquafarm. Cultivation obtained related to cultivation activities including all data especially regarding to the type and amount of feed given to fish and fish production data from each floating net cage system. Data of FCR (Feed Convertion Ratio) was obtained by calculating the ratio between the amount of feed given with the amount of fish produced (tons of feed/tons of fish). Morphometric of reservoir data including total area, volume, depth, outflow, flushing rate, and retention time. Water quality standards and trophic status of lakes/reservoirs are also needed in determining reservoir capacity.

The capacity of pollution loads of lake water and/or reservoirs depends on the characteristics and conditions of the surrounding environment, including morphology and hydrology of lakes and/or reservoirs, water quality and water quality requirements or standards as intended, and allocation of water pollution load from external and internal sources. The calculation of morphology-hydrology of the reservoirs, the allocation of pollutants entering the reservoir, the water pollution load capacity of the lake / reservoir, the capacity of pollution load of aquaculture cultivation on the lake/reservoir, Phosphor waste as the total $\mathrm{P}$ parameter of the remaining feed and fish metabolism waste, total production of KJA cultivation fish and the amount of feed according to capacity was found using the formula based [9] as follows.

1. Morphology dan Hydrology of Reservoir

$\check{Z}$ : mean depth (m)

$$
\breve{Z}=100 \times \mathrm{V}
$$

$\mathrm{V}$ : water volume (juta $\mathrm{m} 3$ )

A : area (Ha)

$$
\rho=\text { Qo / V }
$$

$\rho$ : flushing rate (per year)

$\mathrm{Q}$ : outflow debit (million $\mathrm{m}^{3} /$ tahun)

2. Load Allocation of Phosphorus (P)

Utilization of lakes only for cultivation of fisheries and agriculture or other activities that are not sensitive to level of P-total :

$$
\Delta[\mathrm{P}] \mathrm{d}=[\mathrm{P}] \mathrm{f}-[\mathrm{P}] \mathrm{i}
$$

The Utilization of Multipurpose Lakes Based on Water Quality Standard

$\Delta[\mathrm{P}] \mathrm{d}=[\mathrm{P}] \mathrm{STD}-[\mathrm{P}] \mathrm{i}-[\mathrm{P}] \mathrm{DAS}(4)$

$\Delta[\mathrm{P}] \mathrm{d}$ : alokasi beban P-total budidaya ikan (mg P/m3 )

$[\mathrm{P}] \mathrm{f}$ : maximum P-total requirement in water $\left(\mathrm{mg} \mathrm{P} / \mathrm{m}^{3}\right)$ $\left(\mathrm{mg} \mathrm{P} / \mathrm{m}^{3}\right)$

[P]STD : maximum P-total requirement based on Water Quality Standard

[P]CA : P-total load allocation from Catchment area other than fish farming $\left(\mathrm{mg} \mathrm{P} / \mathrm{m}^{3}\right)$

$[\mathrm{P}] \mathrm{i}$ : P-total of lake water monitoring $\left(\mathrm{mg} / \mathrm{m}^{3}\right)$

3. The Capacity of pollution load from aquaculture
$\mathrm{L}$ fish $=\Delta[\mathrm{P}] \check{Z} \rho /(1-\mathrm{R}$ fish $)(5)$
$\mathrm{R}$ fish $=\mathrm{x}+[(1-\mathrm{x}) \mathrm{R}](6)$ 


$$
\begin{aligned}
& \mathrm{R}=1 /(1+0,747 \rho 0,507)(7) \\
& \text { La fish }=\mathrm{L} \text { fish } \times \mathrm{A}
\end{aligned}
$$

4. Feed and P-Total waste from aquaculture

$$
\mathrm{P}_{\mathrm{LP}}=\mathrm{FCR} \times \mathrm{Pfeed}-\mathrm{Pfish}
$$

$\mathrm{P}_{\mathrm{LP}}$ : P-total load from fish waste to reservoir ( $\mathrm{kg} \mathrm{P} /$ ton ikan)

FCR : Feed Conversion Ratio (ton feed/ton fish)

Pfeed : P-total contet in feed ( $\mathrm{kg} \mathrm{P} /$ ton feed)

\begin{tabular}{|c|c|c|c|c|}
\hline Subjects & Parameters & $\begin{array}{c}\text { Symbo } \\
1\end{array}$ & Unit & $\begin{array}{c}\text { Value } \\
(+185 \mathrm{~m})\end{array}$ \\
\hline \multirow{3}{*}{$\begin{array}{l}\text { Reservoir } \\
\text { morphometry }\end{array}$} & Area & $\mathrm{A}$ & $\mathrm{Ha}$ & 1330 \\
\hline & Volume & $\mathrm{V}$ & juta $\mathrm{m}^{3}$ & 415 \\
\hline & Mean depth & $\check{Z}$ & $\mathrm{~m}$ & 31,20 \\
\hline \multirow{3}{*}{$\begin{array}{l}\text { Reservoir } \\
\text { hydrology }\end{array}$} & Total outflow & $Q_{0}$ & $\begin{array}{l}\text { Million } \\
\mathrm{m}^{3} / \text { year }\end{array}$ & 473,04 \\
\hline & Flushing rate & $\rho$ & year $^{-1}$ & 1,140 \\
\hline & Water Residence Time & Tw & year & 0,877 \\
\hline \multirow{2}{*}{$\begin{array}{l}\text { P standard and } \\
P \text { coefficient } \\
\text { bounding }\end{array}$} & Pstd & Pstd & $\mathrm{mg} / \mathrm{m}^{3}$ & 100 \\
\hline & coefficient of constants & $\mathrm{R}$ & & 0,558 \\
\hline \multirow{2}{*}{$\begin{array}{l}\text { Reservoir } \\
\text { Capacity }\end{array}$} & $\begin{array}{l}\text { Reservoir capacity of P-total } \\
\text { from fish waste per unit area }\end{array}$ & $\mathrm{Li}$ & $\mathrm{gP} / \mathrm{m}^{2} /$ year & 8,012 \\
\hline & $\begin{array}{l}\text { Reservoir Capacity of P- } \\
\text { total based on Morphology } \\
\text { and hydrology }\end{array}$ & $\mathrm{La}$ & ton $\mathrm{P} /$ year & 106,563 \\
\hline
\end{tabular}

Pikan : P-total content in fish ( $\mathrm{kg} \mathrm{P} /$ ton fish)

\section{RESULTS AND DISCUSSION}

The morphometric and hydrological character of the reservoir will determine the processes by which physical, chemical, and biological processes occur in these waters. The physical and chemical characteristic and Capacity of phosphorus load of the Wadaslintang Reservoir is presented in Table 1.

Table 1. Reservoir Capacity of Phosphorus Load based on Morphometri and Hydrology

The average depth of the reservoir is 31.20 meters. Water depth effect on abiotic transport processes related to mass-balances (eg, sedimentation, resuspension, diffusion, burial, mixing and outflow) and also the changes of abiotic factors among lakes influence key foodweb processes concerning production, predation and biomasses of functional groups of organisms (phytoplankton, zooplankton, fish, etc.) [11].

The flushing rate of the Wadaslintang Reservoir was 1.140 million $\mathrm{m}^{3} /$ year or the water retention time was 0.9 years. This duration of water residence depends on the morphometry and hydrology and associated with the characteristic of inflow and outflow of the reservoir. 
This characteristic will affect by the function of reservoirs which further result both phosphorus accumulation in sediments and losses within lakes then bound to sedimentary rocks [12]. This losses are most commonly conceptualized as a function of the area of hydraulic loading rate or mean lake depth and a putative particle settling velocity [13]. However, this phosphorus can be released into the water column when the $\mathrm{pH}$ is in an acidic situation [14].

The form in which phosphorus is supplied to the lake (i.e. inorganic or organic, dissolved or particulate) probably has a particularly important impact on phosphorus retention. If phosphorus is supplied predominantly as soluble reactive $\mathrm{P}$ or as a constituent of animal or human wastes, it can be readily incorporated into the biologic cycle of lakes [15]. Conversely, if it is supplied predominantly in particulate form as $\mathrm{P}$ sorbed onto or incorporated into inorganic particles, it is much less bioavailable to phytoplankton or bacteria. Furthermore, particulate, mineral-bound phosphorus will also settle out of the water column very rapidly and be lost to the sediments. Lakes with long hydraulic retention times trap substantially less phosphorus. Conversely, lakes with short hydraulic retention times trap substantially more TP but the large prediction error is probably due to inadequate lake TP input budgets and the myriad of factors that are known to influence TP losses to lake sediments [13]. However, the phosphorus bound in the sediment will be released into a dissolved state when the condition without oxygen or internal processes of eutrophication [16].

In accordance with the requirements of water quality of lakes and reservoirs stated on the government regulation No. 28/2009 concerning with the Capacity of Water Pollution Load using parameters of P-total in eutrophic trophic status, showed that the water quality of reservoir should meet the Total P standard of $100 \mathrm{ug} / \mathrm{l}$. This condition will be met if the reservoir could fulfill the $\mathrm{P}$ load of 106.66 P/year (Table 1).

Wadaslintang Reservoir is used as a field of fish farming using floating net cages. Based on the method of feeding, it is divided into 2 systems namely semi intensive and super intensive system. Semi-intensive system is a fish cultivation system that feeds do not rely on artificial feed, which is done by fishermen group joined in Forum Komunikasi Tani Nelayan (FKTN) Sejahtera Mandiri. Super intensive feeding system conducted by PT Aquafarm. This feeding system is just relied in artificial feed. Types of feed used is artificial food (pellet) with $25-30 \%$ protein content. Feeding is done in adlibitum for 15 minutes until fish is not eat anymore. This method give possibility that the huge amount of pellet residue that was not consumed by the fish accumulates in the bottom of the water and further contribute to pollution of phosphorus load in the reservoir.

Phosphorus loading is the amount of phosphorus entering the waters caused by fish culture waste using floating net cage. Calculation of the amount of phosphorus loading into the waters can be used to estimate the capacity of the reservoir to meet the requirements of trophic status specified in accordance with its designation. The load capacity of phosphorus contamination shows the maximum concentration of phosphorus element which can be accommodated by Wadaslintang Reservoir based on morphology and hydrology. The load capacity of the phosphorus contents of the Wadaslintang Reservoir was calculated based on Minister of Environment Regulation No. 28 of 2009 about the capacity of pollution load. Table 2 shows the amount of waste from fishery activities that goes to the reservoirs of floating net cage activities managed by community and PT. Aquafarm in Wadaslintang Reservoir. 
Table 2. The load of Phosphorus Load from Aquaculture waste in Wadaslintang Reservoir

\begin{tabular}{lccccc}
\hline Kadar P & $\begin{array}{l}\text { mg P /100 } \\
\text { gr fish } \\
\text { biomasa }\end{array}$ & $\begin{array}{l}\text { g P/ton } \\
\text { fish } \\
\text { biomasa }\end{array}$ & $\begin{array}{l}\text { kg P/ton } \\
\text { fish } \\
\text { biomasa }\end{array}$ & $\begin{array}{l}\text { FC } \\
\text { R }\end{array}$ & $\begin{array}{l}\text { P load (PIp) } \\
\text { Kg/ton } \\
\text { ikan }\end{array}$ \\
\hline $\begin{array}{l}\text { Fish Phosphorus content } \\
\text { from communities } \\
\text { floating net cage }\end{array}$ & 139,2 & 1392 & 1,392 & 1,5 & $\mathbf{3 9 , 1 4 0}$ \\
\hline $\begin{array}{l}\text { Fish Phosphorus content } \\
\text { from PT. Aquafarm } \\
\text { floating net cage }\end{array}$ & 156,43 & 1564,3 & 1,564 & 1,88 & $\mathbf{4 9 , 2 3 6}$ \\
\hline $\begin{array}{l}\text { Fish Feed Phosphorus } \\
\text { content }\end{array}$ & 2702,12 & 27021,2 & 27,021 & & \\
\hline
\end{tabular}

Based on fish production and fish feed consumption calculation, it could be explained that Phosphorus waste from floating net cage of community released to reservoir was up to $39.14 \mathrm{Kg} /$ ton fish. Fish production in floating net cage of community was up to 1.000 tons of fish/year, so the total waste load (Total P) into the reservoir is 39.1 tons/year. For PT. Aquafarm floating net cage the amount of waste to reservoir was up to $49.236 \mathrm{~kg} /$ ton fish. Currently fish production was of 3.600 tons fish/year so that the total load of $\mathrm{P}$ into the reservoir was up to 177.3 tons/year.

The calculation of capacity of $\mathrm{P}$ load from aquaculture activities to Wadaslintang reservoir is presented in Table 3.

Table 3. Wadaslintang Reservoir Capacity to Phosphorus Load and reducing program of Phosphorus

\begin{tabular}{|c|c|c|c|c|c|c|}
\hline Subjects & Parameters & $\begin{array}{l}\text { Symb } \\
\text { ols }\end{array}$ & Units & $\begin{array}{c}\text { Floatin } \\
\text { Communi } \\
\text { ty }\end{array}$ & $\frac{\text { gquafar }}{\text { met }}$ & Total \\
\hline \multirow{9}{*}{$\begin{array}{l}\text { Feed dan } \\
\text { P load } \\
\text { from } \\
\text { floating } \\
\text { net cage } \\
\text { activity to } \\
\text { reservoir } \\
\text { water }\end{array}$} & $\begin{array}{l}\text { Total feed } \\
\text { consumtion }\end{array}$ & LP & ton feed/year & $1.502,9$ & $6.770,7$ & $\begin{array}{r}8.273 \\
, 6 \\
\end{array}$ \\
\hline & $\begin{array}{l}\text { Food Convertion } \\
\text { Ratio }\end{array}$ & FCR & $\begin{array}{l}\text { Ton feed/ton } \\
\text { fish }\end{array}$ & 1,5 & 1,88 & \\
\hline & Feed $\mathrm{P}$ content & $\mathrm{P}$ feed & $\mathrm{Kg} \mathrm{P} /$ ton feed & & & 27,02 \\
\hline & Fish $\mathrm{P}$ content & P ikan & $\mathrm{Kg} \mathrm{P} /$ ton fish & 1.392 & 1.564 & \\
\hline & $\begin{array}{l}\mathrm{P} \text { bound to } \\
\text { sediment }\end{array}$ & $\mathrm{R}$ & & 0,556 & 0,556 & \\
\hline & $\begin{array}{l}\text { P- Total load to } \\
\text { reservoir water }\end{array}$ & $\mathrm{P}_{\mathrm{LP}}$ & $\mathrm{Kg} \mathrm{P} /$ ton ikan & 39,14 & 49,236 & \\
\hline & $\begin{array}{l}\text { Proporsi of } \\
\text { Phosphorus } \\
\text { resuspension } \\
\text { from sediment }\end{array}$ & Rikan & & 0,778 & 0,778 & \\
\hline & $\begin{array}{l}\text { Concentration of } \\
\mathrm{P} \text { in water caused } \\
\text { by aquaculture }\end{array}$ & $\mathrm{dP}$ & $\mathrm{mg} / \mathrm{m}^{3}$ & 18,4 & 83,2 & $\begin{array}{r}102, \\
6\end{array}$ \\
\hline & $\begin{array}{l}\text { Monitoring of } \mathrm{P} \\
\text { in water }\end{array}$ & $\begin{array}{l}\text { dP } \\
\text { obsv }\end{array}$ & $\mathrm{mg} / \mathrm{m}^{3}$ & & & 231,5 \\
\hline
\end{tabular}




\begin{tabular}{|c|c|c|c|c|c|c|}
\hline \multirow{3}{*}{$\begin{array}{l}\text { Load and } \\
\text { reservoir } \\
\text { capacity } \\
\text { of P-total } \\
\text { from } \\
\text { aquacultu } \\
\text { re waste }\end{array}$} & $\begin{array}{l}\text { Reservoir } \\
\text { Capacity of } \mathrm{P} \text { - } \\
\text { Total coming } \\
\text { from aquaculture } \\
\text { waste per unit } \\
\text { area }\end{array}$ & L ikan, & $\mathrm{g} \mathrm{P} / \mathrm{m}^{2} / \mathrm{thn}$ & 2,95 & 13,33 & \\
\hline & $\begin{array}{l}\text { Reservoir } \\
\text { capacity of } \mathrm{P} \\
\text { coming from fish } \\
\text { waste }\end{array}$ & $\begin{array}{l}\mathrm{La} \\
\text { ikan }\end{array}$ & $\mathrm{gP} /$ tahun & $3.923,5$ & $\begin{array}{r}17.728 \\
9\end{array}$ & $\begin{array}{c}21.652 \\
4\end{array}$ \\
\hline & $\begin{array}{l}\text { P-Total Load } \\
\text { from aquaculture } \\
\text { waste to } \\
\text { reservoir }\end{array}$ & $\begin{array}{l}\mathrm{La} \\
\text { ikan }\end{array}$ & ton $\mathrm{P} /$ year & 39,2 & 177,3 & 216,5 \\
\hline \multirow{3}{*}{$\begin{array}{l}\text { Natural } \\
\text { capacity, } \\
\text { exceeded } \\
\mathrm{P} \text { load, } \\
\text { and } \mathrm{P} \\
\text { reducing } \\
\text { program }\end{array}$} & $\begin{array}{l}\text { Capacity of } \\
\text { reservoir based on } \\
\text { morfology and } \\
\text { hydrology }\end{array}$ & $\begin{array}{l}\mathrm{La} \\
\text { reserv } \\
\text { oir }\end{array}$ & ton $\mathrm{P} /$ year & 106,563 & $\begin{array}{r}106,56 \\
3\end{array}$ & $.06,563$ \\
\hline & Exceesive P-Total & & ton $\mathrm{P} /$ year & -67.36 & $\begin{array}{r}+ \\
70.74 \\
\end{array}$ & $\begin{array}{r}+109 . \\
9 \\
\end{array}$ \\
\hline & $\begin{array}{l}\text { Phosphorus } \\
\text { reducing Program }\end{array}$ & & $\%$ & & 39,89 & 50,76 \\
\hline
\end{tabular}

The waste load from the community floating net cage was 39.1 tons/year. It had give impact to Total P content in the reservoir to become $18.4 \mathrm{mg} / \mathrm{m}^{3}$. For the waste load coming from PT Aquafarm was 177.3 ton/year, raises Total P levels in the water reservoir of 83.2 $\mathrm{mg} / \mathrm{m} 3$. The monitoring result of Total $P$ in reservoir water during this study was $231,5 \mathrm{mg} / \mathrm{m}^{3}$, whereas the concentration of $\mathrm{P}$ in caused by aquaculture impact was $102,6 \mathrm{mg} / \mathrm{m}^{3}$. It meant that there was increasing concentration of Phosphorus up to $128,9 \mathrm{mg} / \mathrm{m}^{3}$ might come from human activities in the catchment area beside aquaculture. It could be said that the existence of fish farming system using floating net cage in wadaslintang reservoir has contributed total $\mathrm{P}$ reservoir equal to $43,9 \%$ from total concentration of $\mathrm{P}$ in water.

The impact of aquaculture in the Wadaslintang Reservoir has caused the entry of phosphorus into reservoir of $216.5 \mathrm{~kg} \mathrm{P} /$ ton fish (Table 3). Based on the calculation that the total load of P-total to the reservoir is 39.2 ton P/year for floating net cage of community and 177.3 ton P/year for floating net cage of PT. Aquafarm. While based on morphometry and hydrology, the reservoir capacity should be 106.56 ton P/year. It means that the presence of floating net cage in the Wadaslintang Reservoir has caused the total concentration of $\mathrm{P}$ to exceed its capacity. Based on the amount of feed given by floating net cage of FKTN Sejahtera Mandiri has not exceeded the reservoir capacity, but the floating net cage of Aquafarm of P load from the feed waste has exceeded the capacity of 70,74 ton $\mathrm{P} /$ year or equal to $39,89 \%$ from the requirement. So when summed the incoming $\mathrm{P}$ burden from the aquaculture activity of 216.5 ton/year and has exceeded its carrying capacity of 109.9 ton/ year or $50 \%$ of the total P load into the Wadaslintang Reservoir.

The magnitude load from floating net cage from PT. Aquafarm due to feeding system of adlibitum. Actually, it should be given to the larval phase until the size of the seed instead 
of enlargement phase. If it is given to the larval phase and seeds of larval, their stomach capacity are still very limited so that by feeding them crisply and always available in unlimited quantities, so that they can eat at anytime. Excessive feeding in phase after larvae or seeds will have an impact that decreases water quality and may then be detrimental to aquatic systems in aquaculture activities. Excessive fish feed and not consumed by the fish causes the accumulation of feed in the bottom of the water. According to Abery et al [3] the cage culture operations in Saguling, Cirata and Jatiluhur reservoirs resulted in substantial nutrient loading, due to that the feed discharged into the waters reached $30 \%-40 \%$. Degradation of the accumulation of fish feed and fish feces and fish urine that accumulate in the bottom waters under certain conditions will release toxic materials such as ammonia, $\mathrm{H}_{2} \mathrm{~S}$ that can affect the health of fish cultivation.

The amount of P-total Load to High total phosphorus concentration (total-P) indicates that the organic material entering the water is also high. The limitation of phosphorus can be done by reducing the number of karamba that has passed the threshold and the management of fish feeding is good and appropriate [17]. The management of aquaculture using good and proper karamba will increase the productivity of the fishery itself. Therefore, the activity or production of aquaculture in the waters of the lake should be determined based on the load capacity of the phosphorus contamination. The capacity of lake phosphorus pollution load is the ability of lake water to receive input load of phosphorus contamination without causing lake water to be polluted based on the characteristics and environmental conditions around the lake morphology and hydrology covering area, volume, depth and water discharge; quality and trophic status; water quality standard requirements and allocation of pollution load from various sources and types of water [9]. The load capacity of phosphorus pollution of Rawapening Lake should be determined as control of phosphorus pollution in waters for fishery activity using karamba.

In general, the challenges associated with the floating net cage system include the increase of nutrient content in waters from inedible feed residues, fish excretion and feces, as well as the possible impacts on water quality, environment and ecosystem health conditions [3]. Based on research conducted by [10] fish farming production in floating net cage $(417,9$ ton/year) is still within the permissible limit of watershed reserve capacity (443,9 ton/year), so that KJA cultivation production in Waduk Wadaslintang still possible raised. However, at the time of this study, the production has reached 4600 tons/year, which means that it has increased 10 times and the carrying capacity of the waters has exceeded $50 \%$ of the total production allowed.

\section{CONCLUSIONS}

Wadaslintang Reservoir to phosphorus load capacity based on its morphometry and hydrology was about 106,56 ton P/year. The Phosphorus load from floating net cage was 216,2 ton P/year (39,2 ton/year from FKTN sejahtera mandiri and 177,3 ton P/year from floating net cage of PT. Aquafarm). The P load from PT. Aquafarm have exceeded the capacity as much as 70,74 ton P/year. In general the existence of fish farming system using floating net cage in Wadaslintang Reservoir has contributed to increase the concentration of $\mathrm{P}$ water equal to $43,9 \%$ or in other words as much as $50 \%$ of $\mathrm{P}$ load that goes into reservoir of wadaslintang. Programs designed to reduce the phosphorus load in the wadaslintang could be done by reducing the number of floating net and decreasing all the activities in the catchment area up to $50 \%$ to fulfill phosphorus standard of $100 \mathrm{mg} / \mathrm{m}^{3}$.

Acknowledgement Perum Jasa Tirta I to funding this study. Unsoed for supported the implementation of this study. I would like to express my special thanks of gratitude to Mr. Badruddin Machbub for doing Phosphorus Loading calculation as well as our research team (Gentur Waluyo and 
Diana RUSR) who gave me the golden opportunity to do this wonderful project on the topic (Technical study on the Capacity and Zonation On Wadaslintang Reservoir Waters), which also helped me in doing a lot of Research and I came to know about so many new things, I am really thankful to them. Secondly I would also like to thank the committee of International Conference of Kripik SciFimas Faculty of Fishery and Marine science of Unsoed who have give me opportunity to involve in, and this manuscript could be critically reviewed to become eligible being published to a reputable journal.

\section{REFERENCES}

1 Carballo, Eira; Assiah van Eer, Ton van Schie, Aldin Hilbrands. (2008). Small-scale freshwater fish farming. Agromisa Foundation and CTA, Wageningen

2 Lukman dan Hidayat. 2002. Pembebanan dan Distribusi Organik di Waduk Cirata. Jurnal Teknologi Lingkungan. P3TL-BPPT. Vol. 3 (2): 129 - 135.

3 Abery, N.W; Sukadi, F; Budhiman, A.A.; Kartamihardja, E.S.; Koeshendrajana, S.; De Silva, S.S. 2005. Fisheries and cage culture of three reservoir in west Java, Indonesia : A case study of ambitious development and resulting interactions. Fisheries Management and Ecology 12 (5) : 315 - 330

4 Sukadi, M. F. (2016). Ketahanan Dalam Air Dan Pelepasan Nitrogen \& Fosfor Ke Air Media Dari Berbagai Pakan Ikan Air Tawar. Jurnal Riset Akuakultur, 5(1), 1-12.

5 Garno, Y.S. 2002. Beban pencemaran limbah perikanan budidaya dan eutrofikasi di perairan waduk pada DAS Citarum. J. Tek. Ling. P3TL-BBPT 3 : 112-120.

6 Samudra, S. R. and Soeproboowati, Tri Retnaningsih, Izzati, M. (2013) 'Daya tampung beban pencemaran fosfor untuk budidaya perikanan danau rawapening', Prosiding Penyelamatan Ekosistem danau Rawapening, (June).

7 Erlania, Rusmaedi, Prasetio AB, H. J. (2010) 'Dampak Manajemen Pakan Dari Kegiatan Budidaya Ikan Nila ( Oreochromis niloticus ) Di Keramba Jaring Apung Terhadap Kualitas', prosiding forum Inovasi Teknologi Akuakultur, (2002), pp. 621-631.

8 Piranti, A.S; Waluyo, G.; Rahayu, D.R.U.S.; Carmudi; Christiani. (2016). Kajian Teknis Daya tampung dan Zonasi Perairan Waduk wadaslintang. Laporan Penelitian Kerjasama Perum Jasa Tirta I - LPPM Unsoed Purwokerto.

9 Machbub, B. (2010) '3_Model_perhitungan_daya_tampung_Badruddin.pdf'. Jurnal Sumber Daya Air Vol 6 No 2, pp. 129-144.

10 Widyastuti, E., Piranti, A. S. and Rahayu, D.R.U.S (2009) 'Monitoring Status Daya Dukung (Monitoring of Carrying Capacity Status of Wadaslintang Reservoir on Cage Net )', J. manusia dan Lingkungan, 16(3), pp. 133-140.

11 Hakanson, L. (2015) 'The Importance of Lake Morphometry for the Structure and Function of Lakes', Internat. Rev. Hydrobiol, 90 (4)(August 2005), pp. 433-461. doi: 10.1002/iroh.200410775.

12 Teodorowicz, M. (2013) 'Surface water quality and intensive fish culture', Arch. Pol.Fish, 21, pp. 65-111. doi: 10.2478/aopf-2013-0007. 
13 Brett, M. T. and Benjamin, M. M. (2008) 'A review and reassessment of lake phosphorus retention and the nutrient loading concept', Freshwater Biology, 53, pp. 194-211. doi: 10.1111/j.1365-2427.2007.01862.x.

14 Horne A.J. and Golmand, C.R.,. 1992. Limnology. McGraw Hill Company. New York.

15 Reynolds, C., \& Davies, P., (2001).Sources and Bioavailability of Phosphorus Fractions in Freshwater: A British Perspective. Biological Reviews, 76 (1), 27 - 64

16 Smolders, A. J. P. et al. (2006) 'Internal eutrophication: How it works and what to do about it-a review', Chemistry and Ecology, 22(2), pp. 93-111. doi: $10.1080 / 02757540600579730$.

17 Karakassis, I., Pitta, P. and Krom, M. D. (2005) 'Contribution of fish farming to the nutrient loading of the Mediterranean *', 69(2), pp. 313-321. 